\title{
Computer Game-Based Learning Media as a Strategy to Increase Students' Motivation Learning
}

\author{
Mahasin Husni ${ }^{1}$, Bambang Sumardjoko ${ }^{2}$, Darsinah $^{3}$ \\ ${ }^{1}$ Universitas Muhammadiyah Surakarta, ${ }^{2}$ Universitas Muhammadiyah Surakarta, \\ ${ }^{3}$ Universitas Muhammadiyah Surakarta
}

*Correspondence email: pesan.mahasin@gmail.com

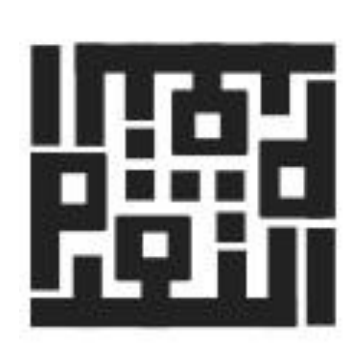

ISSN: $1979-4703(\mathrm{p})$

ISSN: 2527-9726 (e)

Article history:

Received 30 April 2021

Accepted 30 May 2021

Published 30 June 2021

Keywords:

Learning Media, computer games, learning motivation, interest in learning.

\section{A B S T RA C T}

The success of teaching and learning activities is determined by one of the methods and media of learning. This study aims to determine the needs of learning media, develop learning media based on computer games, and determine the effectiveness of learning media based on computer games on students' motivation and interest in learning. This type of research is Research and Development (R\&D), referring to the ADDIE development model. Data collection techniques using observation and questionnaires. The data analysis technique is done by analyzing the questionnaire. The results showed that students needed new learning media with the criteria of using computer technology, game-based, having a colorful display, involving an active role in student participation, easy to operate, equipped with characters, login, and voice access rights. A computer game-based learning media application has been developed called "BEBEB" with a very proper assessment from Media Experts and Material Experts. The effectiveness of the "BEBEB" application as a learning media based on computer games increased learning motivation by $16.5 \%$ and interest in learning by $24.33 \%$. The study results indicate that the development of computer-based learning media as a strategy to increase students' motivation and interest in learning at SMK Muhammadiyah 2 Andong Boyolali has been able to be implemented properly. This implies that teachers need to provide learning media that can arouse students' motivation and interest in learning, one of which is using computer game-based learning media.

\section{Introduction}

Education has a significant role in the progress of a nation as mandated in the Law of the Republic of Indonesia
Number 20 of 2003 concerning the National Education System, which states that national education functions to develop capabilities and shape the character and civilization of a dignified 
nation in the context of the intellectual life of the nation. The law also states that national education aims to develop the potential of students to become human beings who believe and fear God Almighty, have a noble character, are healthy, knowledgeable, capable, creative, independent, and become democratic and responsible citizens. The implementation of quality education, it can give birth to the next generation of quality people. One of the efforts to improve the quality of education is the use of information technology in teaching and learning activities(Fariyani et al., 2020).

Today, the development of technology is very rapid, so creative and innovative efforts are needed to use information technology in teaching and learning activities to develop students' potential. Students will be able to actively develop their potential if they are supported by an educational atmosphere that is meaningful, fun, creative, dynamic, and dialogical.

SMK Muhammadiyah 2 Andong Boyolali is one of the private schools that is currently developing. Because it is located on the border between Boyolali and Sragen districts, SMK Muhammadiyah 2 Andong Boyolali has students with different environmental and social conditions. In the teaching and learning activities at SMK Muhammadiyah 2 Andong Boyolali, there are still many who use the lecture method. The learning media that are often used are in the form of package books and presentation slides. It can be seen that the students lack attention in participating in teaching and learning activities because teaching and learning activities are only monotonous and one-way.

Low student attention indicates low student interest in learning. This is in line with the opinion of Usman (Aritonang, 2008:14), which states that effective learning activities are the attention and interest in learning from students. Interest is a condition where someone pays attention to something accompanied by a desire to know, learn, and prove it. Interest is an asset to grow motivation. According to Elliot, et al. (2000), "motivation is defined as an internal state that arouses us to action, pushes us in particular directions, and keeps us engaged in certain activities." The statement means that motivation is an internal state that arouses us to tend to act and encourages us to achieve certain goals. Arigiyati (200:923) suggests that someone who has high motivation will show interest, attention, total concentration, full of perseverance and lead to achievement regardless of feeling bored, bored, and giving up. If the student's interest is low, the student's motivation to participate in teaching and learning activities is also low.

Looking at these situations and conditions where the teacher tends to be an informant for students. The teacher writes down the subject matter that is considered important on the blackboard. Students tend to be passive in teaching and learning activities. The interaction between students and teachers is almost non-existent. This condition makes students feel bored with teachers who are too dominant in teaching and learning activities. The subject matter should be transferred by the teacher to the minds of 
students and must be constructed into the minds of the students themselves by providing authentic experiences. So teachers as mediators and facilitators need to make creative and innovative efforts in learning that can provide new insights and experiences for students to increase students' motivation and interest in learning in participating in teaching and learning activities. One of them is by using learning media.

The use of learning media in the classroom is still low, and it can even be conveyed that the learning media has never been used by teachers (Sulaimansyah, 2011). However, learning media is a tool for delivering subject matter (Permendikbud Number 22 of 2016). Learning media plays a crucial role in helping the process of teaching and learning activities because of the complexity of the subject matter that cannot be represented through words, and explanations from the teacher can be assisted by learning media. In addition, learning media can be used to attract students' attention. It is also possible that learning media are developed following the developments and demands of the times. For example, learning media developed in the form of computer games.

Developing learning media in computer games will become a different stimulus in learning because, with a more attractive design and appearance, students will feel happier and challenged to complete the game. It is expected to generate motivation and interest in learning from students. Learning media used to support learning activities can utilize existing application programs, such as Yuangga and Sunarsi (2020) research. They are using several pre-existing application programs such as Whatapp, Google Meet, Zoom, and Google Classroom, which are tailored to the needs of its users to overcome distance learning problems during the Covid-19 pandemic. The presentation of learning media can be in various choices such as quizzes, videos, or games. Research conducted by Rosanaya and Fitrayati (2021) developed learning media based on computer games. The use of learning media provides many benefits, one of which is the research conducted by Sunami and Aslam (2021), which uses Zoom Meeting-based animated video learning media to increase elementary school students' interest and learning outcomes. Based on the description above, the objectives formulated in this study are Knowing the needs of learning media, Developing computer game-based learning media, and Knowing the effectiveness of computer game-based learning media on students' motivation and interest in learning.

\section{Literature Review}

Arigiyati (2014:414) that someone who has great motivation will show interest, attention, full concentration, high perseverance, and achievement-oriented without recognizing feelings of boredom, boredom, and giving up. Concerning learning, learning motivation is the overall driving force in students that causes teaching and learning activities, ensuring the continuity of learning activities to achieve learning goals (Krisno Prastyo Wibowo \& Marzuki, 2015:162). I Gusti Made Adnyana (2013:197-198) classifies motivation into 2 , namely: intrinsic and extrinsic motivation. Intrinsic motivation 
is the motivation that arises from within oneself without the need for external stimulation. Sardiman (2011: 90) states, "Intrinsic motivation is inherent in the learning situations and meets pupilsneeds and purpose." Intrinsic motivation is attached to the learning situation so that the goals and needs of students are met. Intrinsic motivation in the teaching and learning process appears by itself attached to students so that learning objectives are achieved. Extrinsic motivation is the motivation that comes from outside the students that helps students in learning. For example, learning media is a tool used by teachers to generate student motivation so that the teaching and learning process becomes more interesting and students can achieve their learning goals.

Subramaniam in I Gusti Made Adnyana and Wardan Suyanto (2013: 196) states, "...interest can be enhanced through manipulating or modifying certain aspects of the learning environment and contextual factors such as teaching strategies, task presentation, and structuring of learning experiences". Interest can be increased by manipulating or modifying certain aspects of the learning environment and contextual factors such as teaching strategies, task presentations, and structuring learning experiences. This means that to increase interest, teachers can manipulate or modify learning strategies and structuring learning experiences. Teachers can use the media as a manipulation tool so that impossible learning experiences can be simulated to increase student interest in learning.
Learning media is a tool for the learning process to deliver subject matter (Permendikbud Number 22 of 2016). According to Nununk Suyani \& Leo Agung (2014), what is meant by learning media is everything that can be used to support efforts to implement the teaching and learning process that leads to the achievement of learning objectives. Seels \& Glasgow (2012:15-18) divide the various types of media into two categories: the choice of traditional media and the choice of the latest technology media. Traditional media options e.g., Projected still visuals (opaque projection, overhead projection, Slides, and Filmstrip), Non-projected visuals (images, posters, photos, charts, graphs, diagrams, exhibits, and info boards), Audio (recordings, cassette tapes, and reels), Print (textbooks, modules, scientific magazines, and sheets), Reality (models, Specimens and Manipulatives (maps, dolls)) and Games. And a choice of cutting-edge technology media. Choice of cutting-edge technology media such as telecommunications-based media (Teleconference and telelecture), Microprocessor-based media (Compact video disc, Hypermedia, Intelligence tutor system, Interactive video, Computerassisted instruction, and computer games

\section{Research Method}

This type of research is Research and Development (R\&D) concerning the ADDIE development model (AnalysisDesign-Develop-Implement-Evaluate). Research and Development (R\&D) is a process or steps to develop a new product or improve an existing product that can be accounted for (Sutama, 2015). The 
place and time of the research were carried out at SMK Muhammadiyah 2 Andong Boyolali from January to April 2021. The research subjects were students of class X majoring in computer network engineering consisting of class $\mathrm{X}$ Creative (TKJ), X TKJ 1, and X TKJ 2 at SMK Muhammadiyah 2 Andong Boyolali.

Sources of data used are primary data (Primary Data) collected by researchers directly in the form of observations and questionnaires about computer gamebased learning media from students. The type of data collected in this study is qualitative data, namely data presented in the form of verbal words, not numbers in the form of input, criticism, and suggestions from students regarding the needs of learning media in teaching and learning activities at SMK Muhammadiyah 2 Andong Boyolali.

Interviews, observations, and questionnaires carried out data collection techniques-interviews and observations in discussion forums to collect validation data from media experts and material experts. Questionnaire to collect data on learning media development needs and students' motivation and interest in learning. Data analysis techniques from interviews and observations using content analysis. In contrast, the data from the questionnaire was analyzed by percentage analysis.

Product development starts from a study to determine the learning media needed by SMK Muhammadiyah 2 Andong Boyolali students. The design stage is done by determining learning tools, flowcharts and designing computer gamebased learning media interfaces. At the Develop stage, it is done by assembling all the components prepared previously at the design stage into a unified development product. The product development is further validated by media experts and material experts as an alternative to improve computer gamebased learning media. The Implement stage is carried out by implementing computer game-based learning media in teaching and learning activities for basic computer network subjects with a material introduction to computer hardware in class X students majoring in network computer engineering at SMK Muhammadiyah 2 Andong Boyolali. The last stage of evaluating is done by evaluating the effectiveness of computerbased learning media to increase students' motivation and interest in learning before and after using computer game-based learning media.

\section{Result and Discussion}

The initial stage of this research is to conduct an analysis phase in the form of an exploratory study using a questionnaire to 104 students consisting of class X TKJ 1, X TKJ 2, X Creative, and XII Creative regarding the learning media used in teaching and learning activities at SMK Muhammadiyah 2 Andong. Boyolali. From an exploratory study using a questionnaire, the following research results were obtained. 


\section{Table 1.}

The results of the study of learning media exploration at SMK Mubammadiyah 2 Andong Boyolali

\begin{tabular}{|c|c|c|c|c|c|}
\hline \multirow{2}{*}{ No. } & \multirow{2}{*}{ Question } & \multicolumn{2}{|c|}{ Total } & \multicolumn{2}{|c|}{ Percent $(\%)$} \\
\hline & & Yes & No & Yes & No \\
\hline 1 & $\begin{array}{l}\text { Does the learning media currently use the } \\
\text { interest you to learn? }\end{array}$ & 40 & 64 & 38,46 & 61,54 \\
\hline 2 & Do you need new learning media? & 93 & 11 & 89,42 & 10,58 \\
\hline 3 & $\begin{array}{l}\text { Does the learning media you need use computer } \\
\text { technology? }\end{array}$ & 75 & 29 & 72,12 & 27,88 \\
\hline 4 & $\begin{array}{l}\text { Are learning media with computer technology } \\
\text { based on games? }\end{array}$ & 77 & 27 & 74,04 & 25,96 \\
\hline 5 & $\begin{array}{l}\text { Does the learning media have a colorful display } \\
\text { (interface design)? }\end{array}$ & 99 & 5 & 95,19 & 4,81 \\
\hline 6 & $\begin{array}{l}\text { Does the learning media involve your active } \\
\text { participation to operate it? }\end{array}$ & 102 & 2 & 98,08 & 1,92 \\
\hline 7 & Can the learning media be operated easily? & 100 & 4 & 96,15 & 3,85 \\
\hline 8 & Is the learning media equipped with character? & 92 & 12 & 88,46 & 11,54 \\
\hline 9 & $\begin{array}{l}\text { Is the learning media equipped with its login } \\
\text { rights (username and password)? }\end{array}$ & 86 & 18 & 82,69 & 17,31 \\
\hline 10 & Is the learning media equipped with sound? & 84 & 20 & 80,77 & 19,23 \\
\hline
\end{tabular}

Based on table 1, the results of the study of learning media exploration at SMK Muhammadiyah 2 Andong Boyolali as a whole above, it can be concluded that the learning media used today do not attract students' interest in learning (61.54\%), students state that they need new learning media $(89.42 \%)$, The learning media needed by students has the following criteria: Using computer technology (72.12\%), Game-based (74.04\%), Having a colorful display (interface design) (95.19\%), Involving active participation you to operate it $(98.08 \%)$, Can be operated easily (96.15\%), Equipped with characters $(88.46 \%)$, Equipped with own login rights (username and password) $(82.69 \%)$ and equipped with by vote $(80.77 \%)$.
Research that produces a product in the form of computer game-based learning media suitable for use has been widely carried out. One of which is research conducted by Mariati (2016), who has conducted research that produces a product in the form of game-based learning media named "Gedutan," which is an accounting education game acronym. As'ad, Yundi Fitrah, Suratno (2013:71) argue that computer technology in education will provide convenience, and learning can be more engaging, effective, and efficient. A Heriyanto, S Haryani, SMR Sedyawati (2013) stated that playing games makes students more enthusiastic, happy, relaxed, and comfortable participating in teaching and learning activities so that they are suitable for use learning media. 


\section{Design}

At this stage, the researchers designed the learning tools and media developed. Learning devices Researchers designed learning tools that include lesson plans, teaching materials, questions, and answers on basic competencies (KD) for parts of computer hardware for basic computer network subjects for Class X students of the Department of Computer Network Engineering at SMK Muhammadiyah 2 Andong Boyolali. Meanwhile, Media, related to educational games that will be developed are flowcharts and interface designs such as logos, buttons, backgrounds, and characters.

\section{Figure 1.}

Flowchart of Computer Game-Based Learning Media

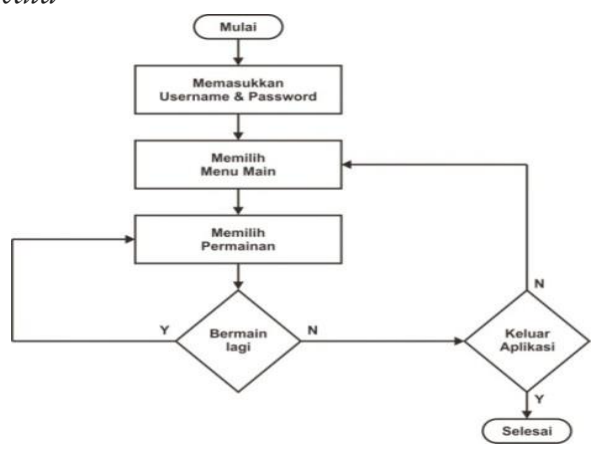

Interface Design. Interface design consists of logos, buttons, backgrounds, and characters. The logo is shown in figure 2. The buttons consist of the Question Button, the Main Button, and the Finish button, as shown in picture 3 . The background design is made with a bright color pattern, as shown in picture 4. Finally, the character designs are made using children's images, as shown in Figure 5.

\section{Figure 2.}

Logo of computer game-based learning media

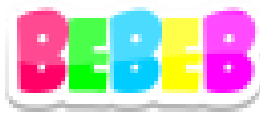

\section{Figure 3.}

Computer game-based learning media buttons

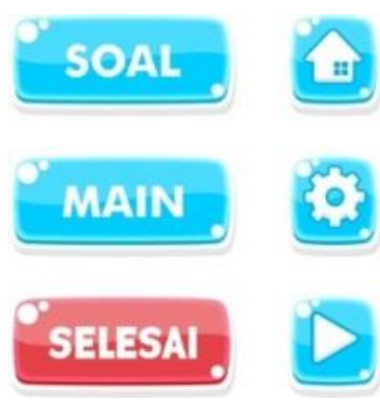

Figure 4.

Background of computer game-based learning media

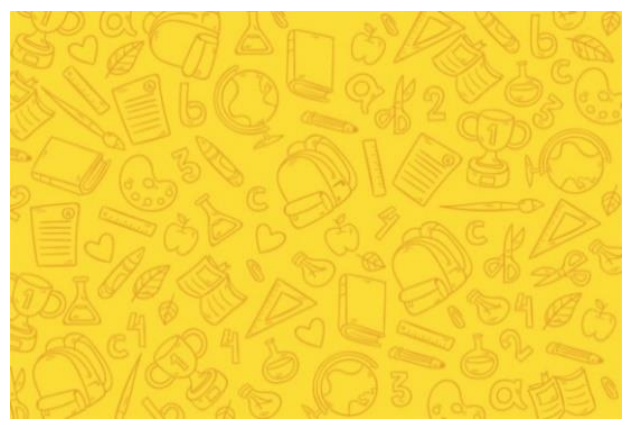

\section{Figure 5.}

Characters of computer game-based learning media

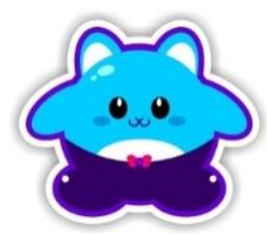




\section{At-Taqaddum}

Vol. 13 No. 1 (2021) Pg. 85-102

\section{Development}

The development stage of computer game-based learning media is carried out by assembling all components prepared previously at the design stage into a single unit using Adobe Dreamweaver CS 6 and Xampp version 1.7.3 according to a flowchart with a specific set of functions. Logos, buttons, backgrounds, and characters are loaded into the learning media program code created using Adobe Dreamweaver CS6. After the interface design and learning, media program code are assembled into a single unit, the teaching materials, questions, and answers are entered into the learning media application program. All teaching materials, questions, and answers are contained in computer game-based learning media by being entered and stored in the Xampp version 1.7.3 database. Based on the validation of media experts on computer game-based learning media as a whole, an average value of 4.25 was obtained in the very feasible category.

Table 2.

Media expert validation test results

\begin{tabular}{clccc}
\hline No. & Assessment Aspect & $\sum$ Score & Average $\sum$ Score & Category \\
\hline 1 & Navigation & 16 & 4,00 & Very Worthy \\
2 & Convenience & 18 & 4,50 & Very Worthy \\
3 & Writing & 26 & 4,33 & Very Worthy \\
4 & Appearance & 25 & 4,17 & Very Worthy \\
& Total & $\mathbf{8 5}$ & $\mathbf{4 , 2 5}$ & Very Worthy \\
\hline
\end{tabular}

Based on the expert validation of material one on computer game-based learning media as a whole, an average value of 4.29 was obtained in the very feasible category.

\section{Table 3.}

Material expert validity test results 1

\begin{tabular}{clccl}
\hline No. & Assessment Aspect & $\sum$ Score & Average $\sum$ Score & Category \\
\hline $\mathbf{1}$ & Learning & 35 & 4,38 & Very Worthy \\
$\mathbf{2}$ & Material & 42 & 4,20 & Very Worthy \\
& Total & $\mathbf{7 7}$ & $\mathbf{4 , 2 9}$ & Very Worthy \\
\hline
\end{tabular}

While the expert validation of material two on computer game-based learning.
Media as a whole obtained an average value of 4.25 in the very feasible category. 
Table 4.

Material expert validity test results 2

\begin{tabular}{clccl}
\hline No. & Assessment Aspect & $\sum$ Score & Average $\sum$ Score & Category \\
\hline $\mathbf{1}$ & Learning & 35 & 4,38 & Very Worthy \\
$\mathbf{2}$ & Material & 46 & 4,60 & Very Worthy \\
& Total & $\mathbf{8 1}$ & $\mathbf{4 , 4 9}$ & Very Worthy \\
\hline
\end{tabular}

Based on the validation of media experts, material one and material two experts

\section{Table 5.}

Revisions and suggestions for improvement provide several revisions and suggestions for improvement

\begin{tabular}{clll}
\hline No. & \multicolumn{1}{c}{ Media Expert } & \multicolumn{1}{c}{ Material Expert 1 } & Material Expert 2 \\
\hline $\mathbf{1}$ & $\begin{array}{l}\text { The display is made } \\
\text { more responsive } \\
\text { Left-aligned writing } \\
\text { question }\end{array}$ & $\begin{array}{l}\text { For good navigation, just change } \\
\text { the box to the arrow next, previous }\end{array}$ & $\begin{array}{l}\text { Thimation is good if there is a little } \\
\text { addition }\end{array}$ \\
$\mathbf{3}$ & $\begin{array}{l}\text { Print results to PDF } \\
\text { any }\end{array}$ & & \\
\hline
\end{tabular}

Revisions and suggestions for improvement that have been given from media experts, material one experts, and material two experts have been carried out on improvements to learning media

The development of computer gamebased learning media resulted in the development of an application called "BEBEB." BEBEB is an abbreviation of the acronym for Learn, Play, and Be Happy. The philosophy of naming $\mathrm{BEBEB}$ on learning media is that by using this computer game-based learning media in teaching and learning activities, students can be helped to learn a subject matter in the form of a game. So that, a feeling of happiness grows in the hearts of each student, which motivates interest in learning students.

The "BEBEB" application is a learning media that is designed, developed, and presented in the form of a game (game) using computer technology in operating it to support fun teaching and learning activities and is expected to arouse students' motivation and interest in learning.

Computer game-based learning media was developed to have advantages, among others: "BEBEB" application is a learning media designed, developed, and presented in the form of a game on a computer. It has an attractive appearance and is easy for students to use. The "BEBEB" application has two types of games, namely TEGA (Guess the Picture) and TEKAT (Guess the Word). The "BEBEB" application can be used on a stand-alone computer, a client-serverbased computer network, or the internet by registering with a hosting and domain. There is a material menu to add insight to students regarding the subject matter 


\section{At-Taqaddum}

Vol. 13 No. 1 (2021) Pg. 85-102

being taught and related to games and a ranking menu to see the ranking of points that students get from each game that has been played. Each question in each game can be added, edited, and deleted. Presentation of questions arranged randomly. The question points in each game can be arranged according to the level of difficulty of the questions. The teacher can see each student's score and point ranking in each game, and the results of the points in each game can be directly printed using a printer and pdf file. Each student has an account that must be registered in the "BEBEB" Application and must enter a username and password to enter the "BEBEB" Application. The "BEBEB" application can be used as a learning medium in all subjects. There is a sound as a background sound when the game is in progress. The "BEBEB" application is an innovation of learning media that has an excellent opportunity to be developed further.

The display of the results of implementing the "BEBEB" application as a learning media based on computer games can be seen on the website www.bebeb.xyz and the display on the game page can be seen in Figure 6 .

\section{Figure 6.}

Display the results of the implementation of the game page

a:s :

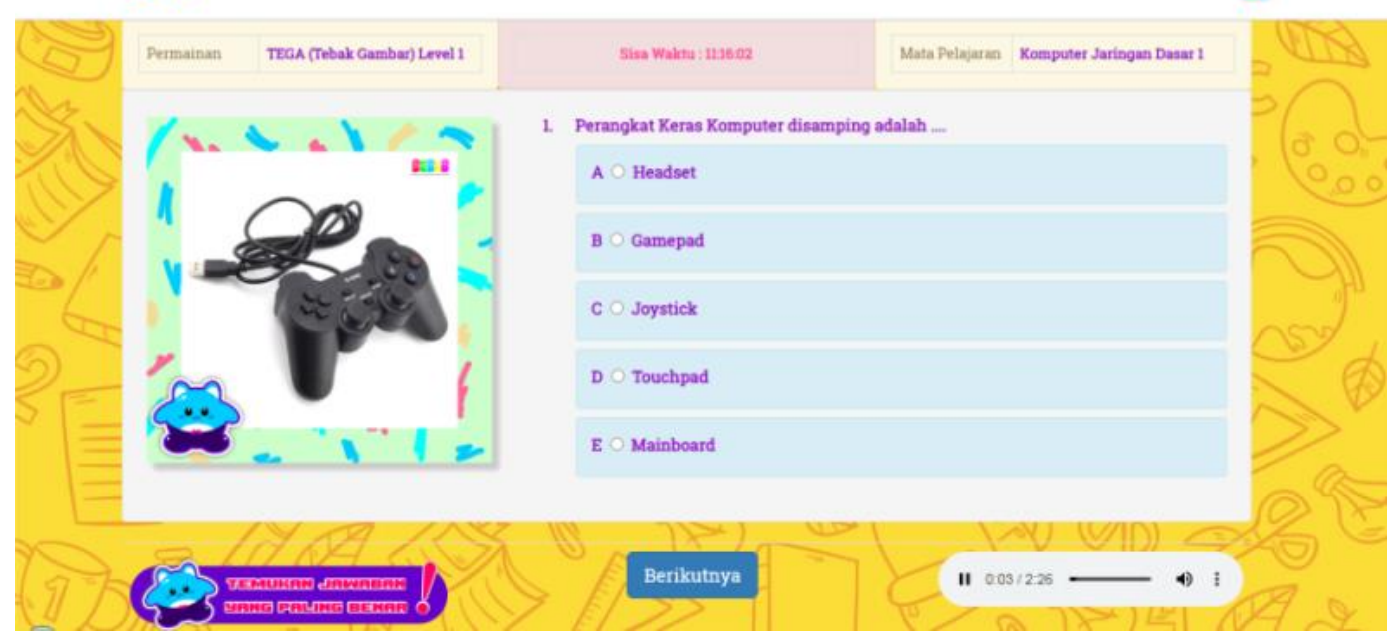

\section{Implement}

Computer game-based learning media is implemented in teaching and learning activities for basic computer network subjects, introducing computer hardware. Which was attended by 75 students of class $\mathrm{X}$ majoring in network computer engineering consisting of class $\mathrm{X}$ Creative (TKJ), X TKJ 1, and X TKJ 2 in SMK Muhammadiyah 2 Andong Boyolali.

At the beginning of teaching and learning activities, students were asked to fill out a questionnaire regarding their motivation 
and interest in learning while participating in learning activities at SMK Muhammadiyah 2 Andong Boyolali. Students are asked to access computerbased learning media located on the computer laboratory server through a web browser application (google chrome, Mozilla Firefox, internet explorer, and so on) on their respective computers by accessing the IP address that has been assigned. Specified on the local network or access the website with the URL address www.bebeb.xyz using an internet connection. Students are asked to enter a username and password first. In computer game-based learning media, there is a material menu so that the teacher can explain the subject matter delivered. At the same time, students open the subject matter delivered by the teacher through computer game-based learning media. After the subject matter is delivered to students, students can try the games contained in computer game-based learning media related to the subject matter presented by the previous teacher.
The teacher can show the ranking of points that have been played to students in each game. At the end of the lesson, students provide responses and opinions by filling out the same questionnaire given at the beginning of the lesson to determine the effectiveness before and after using computer game-based learning media in teaching and learning activities to increase motivation interest in learning. This research resulted in a development product, namely computer game-based learning media on the material of computer hardware parts for students of class $\mathrm{X}$ majoring in computer network engineering at SMK Muhammadiyah 2 Andong Boyolali.

\section{Evaluate}

\section{Student assessment}

Based on table 6, recapitulation of student assessment results before using computer game-based learning media as a whole from a scale of 4 obtained an average value of 2.23 in the feasible category.

Table 6.

Recapitulation of student assessment results before using computer game-based learning media

\begin{tabular}{clccl}
\hline No. & Assessment Aspect & $\sum$ Score & Average $\sum$ Score & Category \\
\hline $\mathbf{1}$ & Motivation & 1580 & 2,63 & Worthy \\
$\mathbf{2}$ & Interest & 1429 & 2,38 & Worthy \\
$\mathbf{3}$ & Attractiveness & 824 & 2,20 & Worthy \\
$\mathbf{4}$ & Convenience & 638 & 1,71 & Not feasible \\
\hline Total & & 4471 & 2,23 & Worthy \\
\hline
\end{tabular}

Based on table 7 , recapitulation of student assessment results after using computer game-based learning media as a whole from a scale of 4 obtained an average value of 3.26 in the very feasible category. 


\section{At-Taqaddum}

Vol. 13 No. 1 (2021) Pg. 85-102

Table 7.

Recapitulation of student assessment results after using computer game-based learning media

\begin{tabular}{clrcl}
\hline No. & Assessment Aspect & $\sum$ Score & Average $\sum$ Score & Category \\
\hline $\mathbf{1}$ & Motivation & 1976 & 3,29 & Worthy \\
$\mathbf{2}$ & Interest & 2013 & 3,36 & Worthy \\
$\mathbf{3}$ & Attractiveness & 1223 & 3,26 & Worthy \\
$\mathbf{4}$ & Convenience & 1181 & 3,15 & Worthy \\
\hline Total & & 6393 & 3,26 & Worthy \\
\hline
\end{tabular}

\section{Figure 7.}

Bar chart sum of values for each aspect before and after

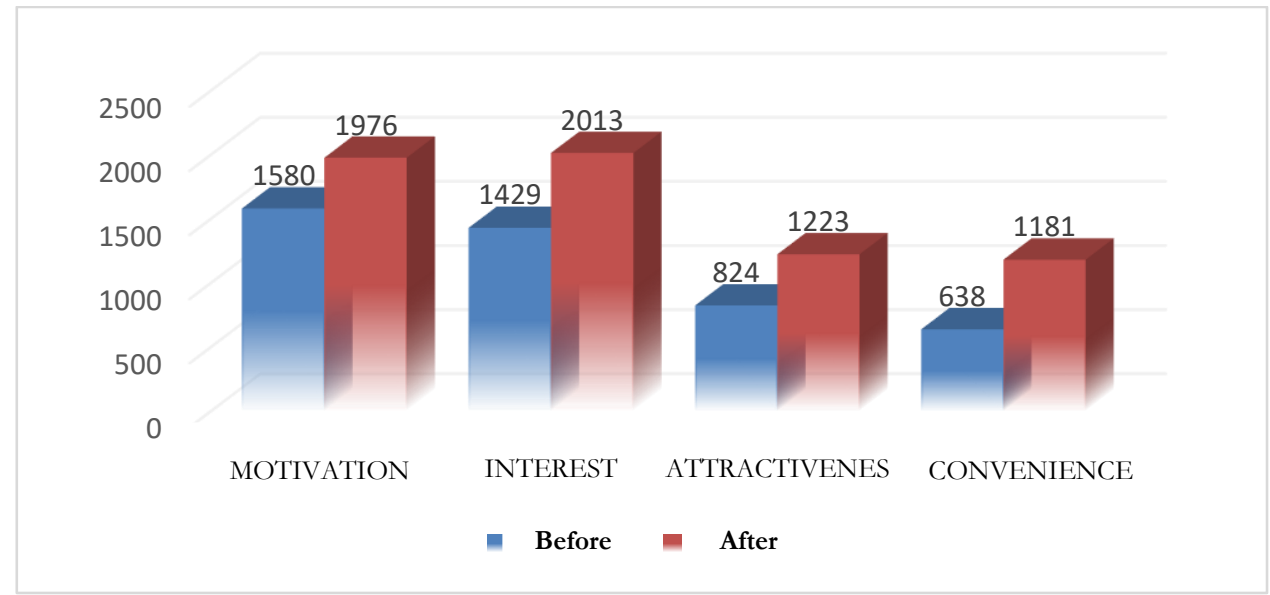

\section{Figure 8.}

Bar chart average value of each aspect before and after

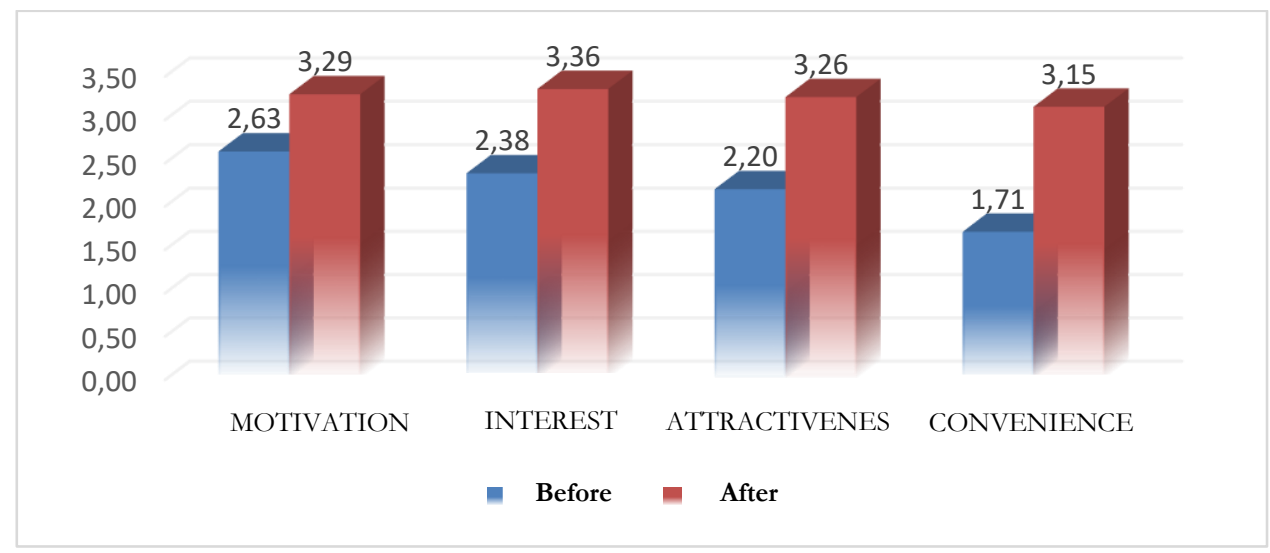




\section{Table 8.}

Recapitulation of the results of improving student assessment before and after using computer gamebased learning media

\begin{tabular}{clccc}
\hline No. & Assessment Aspect & $\sum$ Score & Average $\sum$ Score & Percent \\
\hline $\mathbf{1}$ & Motivation & 396 & 0,66 & 16,5 \\
$\mathbf{2}$ & Interest & 584 & 0,97 & 24,33 \\
$\mathbf{3}$ & attractiveness & 399 & 1,06 & 26,6 \\
$\mathbf{4}$ & Convenience & 543 & 1,44 & 36,09 \\
Total & & $\mathbf{1 9 2 2}$ & $\mathbf{1 , 0 4}$ & $\mathbf{2 5 , 8 8}$ \\
\hline
\end{tabular}

Based on table 8, the recapitulation of the results of increasing student assessment before and after using computer gamebased learning media shows that there is an increase in the average value of 0.66 or $16.5 \%$ from the motivational aspect. From the exciting aspect, an increase in the average value of 0.97 or $24.33 \%$. From the attractiveness aspect, the average value increased by 1.06 or $26.6 \%$. From the convenience aspect, the average value increased by 1.44 or $36.09 \%$. Finally, an increase in the average value of 1.04 or $25.88 \%$ was obtained from the overall average of the four aspects. Therefore, based on the recapitulation table of the increase in student assessment results, it can be concluded that computer game-based learning media can increase students' motivation and interest in learning at SMK Muhammadiyah 2 Andong Boyolali. This is in line with what Adnyana and Suyanto (2013) stated that learning media can increase students' motivation and interest in learning. The same thing was also stated by Keke T. Aritonang (2008), who stated that using learning media can make learning more effective to generate motivation and interest in students' learning. Therefore, the role of the teacher as facilitator and mediator is needed.

The recapitulation of the validation of media experts, material experts, and student assessments as a whole can be seen in table 9.

\section{Table 9.}

Recapitulation of the validation results of media experts, material experts, and student assessments

\begin{tabular}{clcccc}
\hline No. & Respondent & Actual Score & Ideal Score & Percent (\%) & Category \\
\hline $\mathbf{1}$ & Media Expert & 85 & 100 & $85 \%$ & Very Worthy \\
$\mathbf{2}$ & Material Expert 1 & 77 & 90 & $85,56 \%$ & Very Worthy \\
$\mathbf{3}$ & Material Expert 2 & 81 & 90 & $90 \%$ & Very Worthy \\
$\mathbf{4}$ & Student & 6393 & 7800 & $81,96 \%$ & Very Worthy \\
\hline
\end{tabular}


Figure 11.

Bar chart of the actual score percentage of media experts, material experts, and students

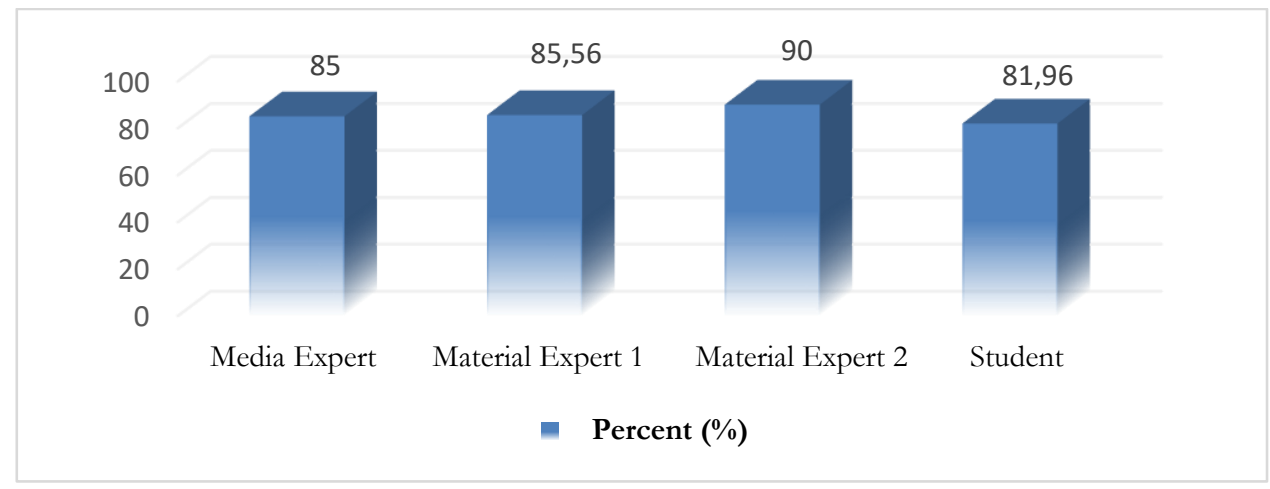

Based on table 9, recapitulation of the validation results of media experts, material experts, and overall student assessments above. It can be seen that computer gamebased learning media from media expert validation obtained an actual value percentage of $85 \%$ in the very feasible category. From material expert validation, 1 obtained a percentage of the actual value of $85.56 \%$ in the very feasible category, from expert validation two the percentage of the actual value of $90 \%$, and student assessments obtained the percentage of the actual value of $81.96 \%$ in the very feasible category. Therefore, based on the recapitulation of the validation results from media experts, material experts, and student assessments. It can be concluded that this computer game-based learning media is suitable for being used as a learning medium to increase students' motivation and interest in learning at SMK Muhammadiyah 2 Andong Boyolali. Aritonang (2008) states that teachers as facilitators must be able to determine and manage methods, strategies, and motives in teaching so as to increase students' motivation and interest in learning.

\section{Conclusions}

Based on the results of research and discussion, based on an exploratory study conducted on 104 students, it can be concluded that the learning media used today have not attracted students' interest in learning. Students need new learning media with the criteria of using computer technology, based on games, a colorful display (interface design), and an active role. Student participation, easy to operate, equipped with characters, own login permissions, and voice. The "BEBEB" application has been developed to assess media experts getting an average value of 4.25 in the very appropriate category. Material expert 1 obtaining an average value of 4.29 in the very appropriate category, material expert 2 obtaining an average value of 4, 49 in the very feasible category, student assessments obtained an average value of 3.26 in the very feasible category. The effectiveness of the "BEBEB" application as a learning media based on computer games can increase students' learning motivation by $16.5 \%$ with an average value of 0.66 , student 
interest in learning by $24.33 \%$ with an average value of 0.97 , attractiveness by 26 $.6 \%$ with an average value of 1.06 and convenience of 36.09 with an average value of 1.44 .

\section{Recommendation}

The "BEBEB" application needs to be further developed using a 3-dimensional (3D) display so that it can load moving animations. The "BEBEB" application also needs to be further developed on mobile platforms such as Android and iOS so that it can be used on smartphones. It would be nice to do further research on the use of the "BEBEB" application as a computer game-based learning media in other schools so that more varied research results can be obtained.

\section{References}

Adita, A., Kusuma, A.B. \& Risnani, L.S. (2017). Analisis Kebutuban Game Edukasi MIPA. Jurnal Bioedukatika, 5, 86-91

Adnyana, I G.M., \& Suyanto, W. (2013). Penggunaan EFI SCANNER sebagai Media Pembelajaran untuk Meningkatkan Minat, Motivasi, dan Prestasi Belajar Siswa. Jurnal Pendidikan Vokasi, 3.

Arigiyati dalam Retno Puspitorini, A.K. Prodjosantoso, Bambang Subali, \& Jumadi. (2014). Penggunaan Media Komik dalam Pembelajaran IPA untuk meningkatkan Motivasi dan Hasil Belajar Kognitif dan Afektif. Cakrawala Pendidikan

Aritonang, K.T., (2008). Minat dan Motivasi dalam Meningkatkan Hasil Belajar Siswa. Jurnal Pendidikan Penabur. 7, 11-21

Arsyad, Azhar. (2006). Media Pembelajaran. Jakarta: PT Raja Grafindo Persada

As'ad, Fitrah, Y., Suratno. (2013).
Pengembangan Media Pembelajaran untuke Mata Pelajaran Kewirausabaan di SMK dengan Menggunakan Aplikasi Macromedia Flash. Tekno-Pedagogi, 3, 69-86

Azmi, R.A., Rukun, K. \& Maksum, H. Analisis Kebutuban Pengembangan Media Pembelajaran Berbasis Web Mata Pelajaran Administrasi Infrastruktur Jaringan. Jurnal Ilmiha Pendidikan dan Pembelajaran, 4, 303-314

Desstya, A., Haryono, Saputro, S. (2012). Pembelajaran Kimia dengan Metode Teams Games Tournaments (TGT) Menggunakan Media Animasi dan Kartu Ditinjau dari kemampuan Memori dan Gaya Belajar Siswa. Jurnal Inkuiri Universitas Sebelas Maret ISSN : 2252-7893, 1, 177-182

Dewi, G.P.F. (2012). Pengembangan Game Edukasi Pengenalan Nama Hewan Dalam Bahasa Inggris Sebagai Media Pembelajaran Siswa SD Berbasis Macromedia Flash. Skripsi. Yogyakarta: Universtias Negeri Yogyakarta

Dimyati dan Mudjiono. (2006). Belajar dan Pembelajaran. Jakarta: PT. Rajagrafindo Persada

Fariyani, Q., Mubarok, F. K., Masfu'ah, S., \& Syukur, F. (2020). Pedagogical Content Knowledge of Pre-service Physics Teachers. Jurnal Ilmiah Pendidikan Fisika Al-BiRuNi, 9(1), 99107.

https://doi.org/10.24042/jipfalbirun i.v9i1.3409

Hamdu, G. \& Agustina, L. (2011. Pengaruh Motivasi Belajar Siswa Terhadap Prestasi Belajar di Sekolah Dasar. Jurnal Penelitian Pendidikan, 12, 90-96

Heriyanto, A., Haryani, S., Sedyawati, SMR. (2013). Pengembangan Multimedia Pembelajaran Interaktif Berbasis Education Game Sebagai Media Pembelajaran Kimia. Chemistry in Education Universitas Negeri Semarang, 2252-6609 
Hidayah, Fitri. (2012). Penerapan E Learning sebagai Media Pembelajaran Mata Diklat Pemrograman Web Kelas XI Teknik Komputer Jaringan SMK N 2 Pengasih. Skripsi. Yogyakarta: Universitas Negeri Yogyakarta.

Huda, Ahmad Samsul. (2016). Game Edukasi Cepat Tepat dengan Metode Finite State Machine (FSM) pada Smartphone. Skripsi. Malang: Universitas Islam Negeri Maulana Malik Ibrahim

Indaryati \& Jailani. (2015). Pengembangan Media Komik Pembelajaran Matematika Meningkatkan Motivasi dan Prestasi Belajar Siswa Kelas V. Jurnal Prima Edukasia, 3, 84 - 96.

Kartika, H. (2014). Pembelajaran Matematika Berbantuan Software Matlab sebagai Upaya Meningkatkan Kemampuan Komunikasi Matematis dan Minat Belajar Siswa SMA. Jurnal Pendidikan UNSIKA, 2, 2338-2996

Lutfiyatun, Eka. (2015). Pengembangan Media Game Edukasi Berbasis Adobe Flash CS5 pada Keterampilan Menulis Bahasa Arab untuk Siswa Kelas VII MTs. Skripsi. Semarang: Universitas Negeri Semarang.

Mariati. (2016). Pengembangan Media Pembelajaran Multimedia Interaktif Model Games "Gedutan" dalam Pembelajaran Akutansi pada Siswa Kelas X SMK-BM se-kota Medan. Seminar Nasional Pendidikan.

Nashar. 2004). Peranan Motivasi dan Kemampuan Awal dalam Kegiatan Pembelajaran. Jakarta: Delia Press.

Nugraha, A,P. Raharjo, T., Wahyuningsih, D. (2013). Pengembangan Media Pembelajaran Fisika Menggunakan Ular Tangga Ditinjau dari Motivasi Belajar Siswa Kelas VIII Materi Gaya. Jurnal Pendidikan Fisika, 16, 11.

Nugraha, A.P.,
Wahyuningsih,
Pengembangan Media Pembelajaran Fisikea Menggunakan Permainan Ular Tangga Ditinjau Dari Motivasi Belajar Siswa Kelas VIII Materi Gaya. Jurnal Pendidikan Fisika, 1, 1.

Nugrahani, R. (2007). Media Pembelajaran Berbasis Visual Berbentuk Permainan Ulat Tangga untuk Meningkatkan Kualitas Belajar Mengajar di Sekolah Dasar. Lembaran Ilmu Kependidikan Universitas Negeri Semarang Jilid 36

Nurhasanah, S., \& Sobandi, A. (2016). Minat Belajar Sebagai Determinan Hasil Belajar Siswa. Jurnal Pendidikan Manajemen Perkantoran, 1, 128-135

Permendikbud Nomor 22 Tahun 2016

Putra, Ditto Rahmawan. (2016). Perancangan Game Edukatif Berbasis Android sebagai Media Pembelajaran Akutanasi di Kelas XI IPS SMA Negeri 1 Imogiri pada Materi Jurnal Penyesuaian Perusahaan Jasa. Skripsi. Yogyakarta: Universitas Negeri Yogyakarta.

Rosanaya, L.R. \& Fitrayati, D. (2021). Pengembangan Media Pembelajaran Berbasis Video Animasi pada Materi Jurnal Penyesuaian Perusahaan Jasa. Jurnal BASICEDU, 3, 2258-2267.

Santyasa, Wayan. (2007). Landasan Konseptual Media Pembelajaran. Makalah, Workshop. Klungkung: Fakultas Pendidikan Matematika dan Ilmu Pengetahuan Alam Universitas Pendidikan Ganesha.

Slameto. (2010). Belajar dan Faktor-faktor yang Mempengarubinya. Jakarta: Rineka Cipta

Sunami, M.A., \& Aslam. (2021). Pengarub Penggunaan Media Pembelajaran Video Animasi Berbasis Zoom Meeting terhadap Minat dan Hasil Belajar IPA Siswa Sekolah Dasar. Jurnal BASICEDU, 5, 1960-1945.

Suseno, Argo. (2010). Manfaat Game dalam Kegiatan Belajar. Diakses dari http://argosus.wordpress.com/2010 
/02/23/manfaat-game-dalamkegiatan-belajar/ diakses pada tanggal 14 Juni 2017

Sutama. 2010. Metode Penelitian Pendidikan Kualitatif, Kuantitatif, PTK, $\mathrm{R} \& D$. Surakarta: Fairuz Media

Syamsudin, A. 1996. Psikologi Kependidikan. Bandung: PT. Remaja Rosda Karya

Syarif, I. 2012. Pengaruh Model Blended Learning Terhadap Motivasi dan Prestasi Belajar Siswa SMK. Jurnal Pendidikan Vokasi, 2.

Undang-undang Nomor 20 Tahun 2003 Pasal 3 Tentang Sistem Pendidikan Nasional.

Usman, Uzer. (2003). Menjadi guru profesional. Bandung: PT. Remaja Rosdakarya

Wibowo, K.P \& Marzuki. (2015). Penerapan Model Make a Match Berbantuan Media untuk Meningkatkan Motivasi dan Hasil Belajar IPS. Harmoni Sosial: Jurnal Pendidikan IPS, 2, 158-159.

Yuangga, K.D., \& Sunarsi, D. (2020). Pengembangan Media dan Strategi Pembelajaran untuk Mengatasi Permasalahan Pembelajaran Jarak Jauh di Pandemi Covid-19. Guru Kita, 4, 51-58. 
At-Taqaddum

Vol. 13 No. 1 (2021) Pg. 85-102

$102 \mid \mathrm{P}$ a g e 